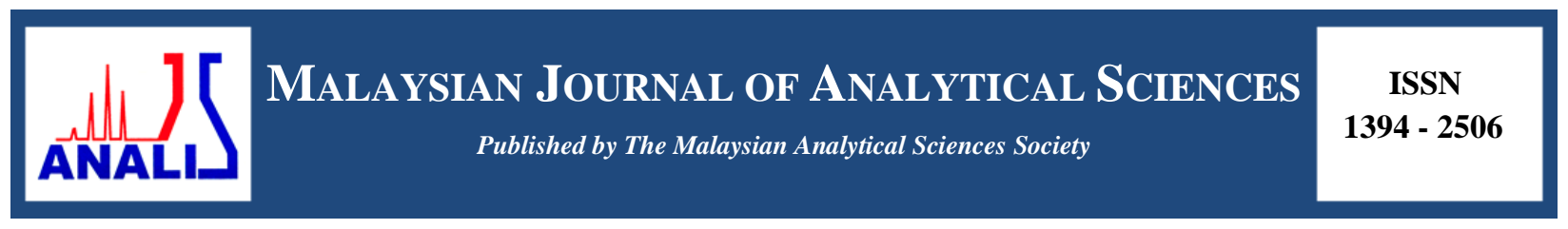

\title{
SEPARATION OF FATTY ACIDS FROM PALM OIL USING ORGANIC SOLVENT NANOFILTRATION
}

\author{
(Pemisahan Asid Lemak daripada Minyak Kelapa Sawit Menggunakan Penuras Nano Pelarut \\ Organik)
}

\author{
Dayang Nur Fitrah Awang Ismail and Nazlee Faisal Ghazali* \\ Department of Bioprocess Engineering, \\ Faculty of Chemical and Energy Engineering, \\ Universiti Teknologi Malaysia, 81310 Skudai, Johor Bahru, Johor, Malaysia \\ *Corresponding author: nazlee@utm.my
}

Received: 16 April 2017; Accepted: 7 March 2018

\begin{abstract}
Distillation of fatty acid from traditional recovery method consumes a lot of energy. Membrane process is more preferred because it reduces energy consumption. In this work, the possibility of separating free fatty acid (FFA) from palm oil using organic solvent nanofiltration was studied. Various commercial organic solvent nanofiltration membranes were tested using dead end filtration for their ability to remove free fatty acid from palm oil/acetone mixture. In all membranes, triglycerides (TAG) were preferentially retained at increasing pressure, while FFA were permeated through the membrane. All the three membranes showed selective permeation of FFA, with Solsep 030306 gave the highest selectivity of FFA over triglycerides. The best fatty acid separation performance was achieved using NF030306 membrane with acetone at pressure in the range of 30 to 40 bar and $3.6 \mathrm{~g} / \mathrm{L}$ concentration of fatty acid. Using NF030306 membrane, 55\% of low fatty acid and 87\% of triglycerides were rejected from the system. Good separation was achieved at high pressure and concentration. We successfully demonstrated the separation of fatty acid separation from palm oil using organic solvent nanofiltration could be achieved.
\end{abstract}

Keywords: free fatty acid, palm oil, organic solvent nanofiltration, deacidification

\begin{abstract}
Abstrak
Pemulihan tradisional asid lemak daripada minyak yang boleh dimakan menggunakan sejumlah besar tenaga. Jika penyulingan digantikan dengan proses membran, penggunaan tenaga boleh dikurangkan dengan banyak. Dalam kajian ini, kami akan mengkaji kemungkinan untuk memisahkan asid lemak bebas daripada minyak kelapa sawit dengan menggunakan penuras nano pelarut organik. Pelbagai pelarut organik membran penuras nano komersial telah diuji menggunakan penuras nano untuk keupayaan mereka untuk memisahkan asid lemak bebas daripada campuran kelapa sawit/aseton. Untuk semua membran, trigliserida adalah dikekalkan pada tekanan yang semakin meningkat, manakala asid lemak meresap melalui membran. Ketigatiga membran menunjukkan penyerapan terpilih asid lemak, bagaimanapun Solsep 030306 memberikan pemilihan tertinggi asid lemak/trigliserida. Pemisahan asid lemak yang terbaik dicapai dengan menggunakan membran NF030306 dengan aseton pada tekanan dalam lingkungan 30 hingga 40 bar dan $3.6 \mathrm{~g} / \mathrm{L}$ kepekatan asid lemak. Penolakan asid lemak yang rendah iaitu 55\% dan penolakan trigliserida yang tinggi sehingga 87\% telah dicapai menggunakan membran NF030306. Pemisahan baik dicapai pada tekanan tinggi dan kepekatan tinggi. Ia menunjukkan pemisahan asid lemak daripada minyak kelapa sawit menggunakan penuras nano pelarut organik boleh dicapai.
\end{abstract}

Kata kunci: asid lemak bebas, minyak sawit, penuras nano pelarut organik, penyahasidan 


\section{Dayang Nur Fitrah \& Nazlee Faisal: SEPARATION OF FATTY ACIDS FROM PALM OIL USING ORGANIC SOLVENT NANOFILTRATION}

\section{Introduction}

In palm oil processing, free fatty acid (FFA) has to be separated from crude palm oil because they adversely affect end-product quality. Currently free fatty acid removal from palm oil, a typical deacidification method for palm oil is steam distillation whereby the process is operated at $240-260{ }^{\circ} \mathrm{C}$ at of 1 to $3 \mathrm{~mm} \mathrm{Hg}$ pressure [1]. However, this conventional process is energy-intensive and operated at high temperature which could destroy valuable thermal sensitive compounds. On the other hand, membrane separation offers several advantages over conventional process such as ambient temperature, less energy usage and reduction of thermal damage.

From the literature, researchers had tried the method of deacidification process of vegetable oil using membranes with and without the addition of solvent. Bhosle et al. used polymeric dense membranes to recover fatty acid from sunflower oil without any solvent but the selectivity between fatty acid and glycerides was low [2]. Some researchers used coupled extraction and membrane separation for fatty acid extraction from vegetable oil. For example, methanol was used to extract free fatty acids from soybean oil, where recovery the methanol was done using nanofiltration [3]. In addition, Kale et al uses methanol to extract free fatty acids from rice bran oil, and then to concentrate the free fatty acids and recover the methanol using reverse osmosis membranes [4]. Kumar and Bhowmick used membranes separation of FFA and glycerides from groundnut oil and showed that the selectivity between fatty acid and glycerides was low [5]. Firman et al. used commercial membrane and in-house fabrication PVDF membrane to deacidify soybean oil and solvent recovery by nanofiltration [6]. Currently, organic solvent nanofiltration (OSN) is becoming a great deal of attention for alternative molecular purification technology because of its low energy usage and ambient temperature operation [7, 8]. Organic solvent nanofiltration, it is sometimes called solvent resistant nanofiltration where a pressure driven membrane process that uses solvent resistant membranes to separate solutes of 100 to $1000 \mathrm{Da}$. The current applications of organic solvent nanofiltration (OSN) include solvent recovery [9,10], catalyst recycling [11], enantiomer separation [12], peptide synthesis [13], and pharmaceutical purification [14].

The objective of this study was to remove free fatty acid from palm oil using organic solvent nanofiltration and to study the effects of pressure and concentration on the separation performance. This is the first time membrane was used to separate fatty acid from palm oil using OSN. To investigate the separation performance in deacidification of crude palm oil, various membranes were used in the experiments. A synthetic solution consists of palm oil and fatty acid was made. The molecular weight of palm oil is $847.78 \mathrm{~g} / \mathrm{mol}$ and palmitic acid is $256.43 \mathrm{~g} / \mathrm{mol}$ [15]. The performance is measured by the permeate flux and the rejection of solutes. The comparison of membrane performance was investigated through different pressure applied, and different concentration of free fatty acid contained in the oil feed.

\section{Materials}

\section{Materials and Methods}

Refined cooking oil was purchased from local store and the palmitic acid was purchased from Sigma-Aldrich. All membranes (NF030306, NF030306F, NF010206, and NF010306) were purchased from SOLSEP, Netherland. The properties of each membrane are shown in Table 1 . The separation characteristics were measured by the rejection of solutes.

\section{Membrane preparation}

Each membrane was cut into circular disc with $20.43 \mathrm{~cm}^{2}$ area and fitted in a dead-end nanofiltration set-up equipped to stainless steel feed tank under nitrogen atmosphere at $25^{\circ} \mathrm{C}$. NF030306 membrane was used in this experiment where it was tested using different solvents (acetone, hexane, isopropyl alcohol and ethyl acetate) at constant temperature, $25^{\circ} \mathrm{C}$, constant transmembrane pressure, 30 bar and stirred at $400 \mathrm{rpm}$.

\section{Oil preparation}

To represent as a crude palm oil, the feed sample was prepared by mixing the refined cooking palm oil with palmitic acid (4 wt.\%). Solvent was added to the fatty acid-palm oil mixture due to high viscosity of the model solution. This solution was then filtered using dead end nanofiltration cell. 


\section{Measurement of free fatty acid concentration}

The concentration of fatty acid in the feed, permeate and retentate was measured using GC. All experiments were performed in duplicate, the mean values were reported, and the differences between mean were statistically significant.

Table 1. Separation characteristics of SOLSEP membranes.

\begin{tabular}{lc}
\hline $\begin{array}{l}\text { SOLSEP } \\
\text { Membrane }\end{array}$ & $\begin{array}{c}\text { Rejection of solutes R } \\
\text { (Molecular Mass of Solutes) }\end{array}$ \\
\hline NF010206 & $95 \%(300 D a)$ \\
NF010306 & $95 \%(500 D a)$ \\
NF030306F & $95 \%(300 D a)$ \\
NF 030306 & $95 \%(500 D a)$ \\
\hline
\end{tabular}

$$
\text { Rejection }=1-(\mathrm{Cp} / \mathrm{Cr}) * 100
$$

where $\mathrm{Cp}$ is the permeate concentration and $\mathrm{Cr}$ is the retentate concentration

\section{Membrane preparation}

Each membrane (NF030306, NF030306F, NF010206 and NF010306) was cut into circular disc with $20.43 \mathrm{~cm}^{2}$ area and fitted in a dead-end nanofiltration set-up equipped to stainless steel feed tank under nitrogen atmosphere at $25{ }^{\circ} \mathrm{C}$.

\section{Optimization of membrane efficiency in the filtration process}

The best membrane from membrane selection experiment was chosen. Filtration experiment was operated using different pressure; $10 \mathrm{bar}, 20 \mathrm{bar}, 30 \mathrm{bar}$, and $40 \mathrm{bar}$. The temperature and stirring speed was kept constant at $25{ }^{\circ} \mathrm{C}$ and $400 \mathrm{rpm}$, respectively. For the concentration variation experiment, The concentration of fatty acid (palmitic acid) in feed were $1.7 \mathrm{~g} / \mathrm{L}, 3.6 \mathrm{~g} / \mathrm{L}, 7.2 \mathrm{~g} / \mathrm{L}$ and $14.4 \mathrm{~g} / \mathrm{L}$ at constant pressure. For all filtration, the retentate and permeate was collected and analysed.

\section{Analysis of free fatty acid and triglycerides}

The fatty acid concentration was determined using gas chromatography (GC) AutoSystem XL (Shimadzu, Japan) while the analysis of triglycerides was done using evaporation method where $1 \mathrm{ml}$ of sample was used and left to evaporate to remove solvents.

\section{Optimisation of performance parameter}

The important parameters that measure the performance of a membrane are flux and rejection. Flux $\mathrm{J}\left(\mathrm{L} / \mathrm{m}^{2} . h=\right.$ $L M H$ ) expressed as shown in equation 2:

$$
J=\frac{V}{A \cdot t}
$$

where $V$ corresponds to the volume of accumulated permeate (L), $A$ is the membrane effective area $\left(\mathrm{m}^{2}\right)$ and $t$ is the filtration time (h).

The observed solute rejection $R_{i}$ for a given species $\mathrm{i}$ is given by equation 3 below:

$$
R_{i}=\left(1-\frac{C_{i p}}{C_{i r}}\right) \times 100 \%
$$




\section{Dayang Nur Fitrah \& Nazlee Faisal: SEPARATION OF FATTY ACIDS FROM PALM OIL USING ORGANIC SOLVENT NANOFILTRATION}

where $C_{i p}$ is the concentration in permeate while $C_{i r}$ is the corresponding retentate concentration. An ideal membrane would allow all free fatty acids to pass through the membrane, while retaining all of triglycerides or in other hand, a high rejection for triglycerides and a low rejection of free fatty acids.

\section{Selection of membrane}

\section{Results and Discussion}

Figure 1 shows the permeate flux profile for each membranes tested. Permeate flux for NF010206 shown the highest (58.737 LMH) from the membranes tested while NF030306F was the lowest with 11.569 LMH permeate flux. A decline in permeate flux with time was observed in all samples. The decrease in flux permeation may be due to concentration polarization, membrane compaction, formation of gel layer and pore blocking of the membrane [16]. The best membrane in term of flux performance was NF010206. However, performance parameter such as rejection of free fatty acids and triglycerides along with the selectivity factor need to be taken into consideration too.

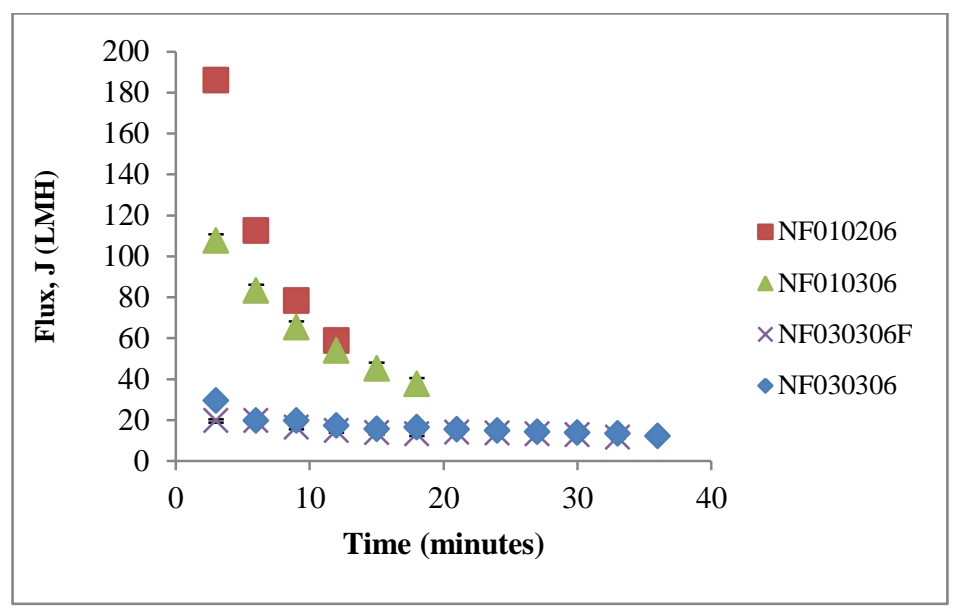

Figure 1. Flux profile for each membrane (Operation conditions: $30 \mathrm{bar}, 25^{\circ} \mathrm{C}$ and agitation $400 \mathrm{rpm}$ with $100 \%$ pure acetone)

Figure 2 shows the rejections of free fatty acid and triglycerides for various membranes. It is desired to obtain the lowest possible percent of rejections of free fatty acids while the maximum possible rejection of triglycerides. From Figure 2, the lowest percent rejection of FFA was obtained by using NF010306 with $56.22 \%$ followed by NF030306 and NF030306 with 56.28\%, respectively. Moreover, NF010206 and NF030306F were discarded for not presenting reasonable percent rejections, which were over $60 \%$ rejections of free fatty acids. The highest percent triglycerides rejection was obtained using NF010206 $(\mathrm{R}=89.04 \%)$, however the rejections of fatty acid was also high $(\mathrm{R}=86.41 \%)$ indicates that the separation was not efficient. This also applies with NF030306F which also gave high percent of free fatty acid rejection $(\mathrm{R}=86.46 \%)$ This is expected since the molecular weight cutoff (MWCO) of NF010206 and NF030306F is around 300 Da. However, good separation was achieved using NF010306, and NF030306 since their values of percent rejections was quite high for rejection of triglycerides $(\mathrm{R}=$ $87.65 \%)$ and low percent for rejections of free fatty acid $(\mathrm{R}=56.28 \%)$. As both membrane has $500 \mathrm{Da}$ MWCO, it was expected for them to easily permeating free fatty acid while retaining the triglycerides. 


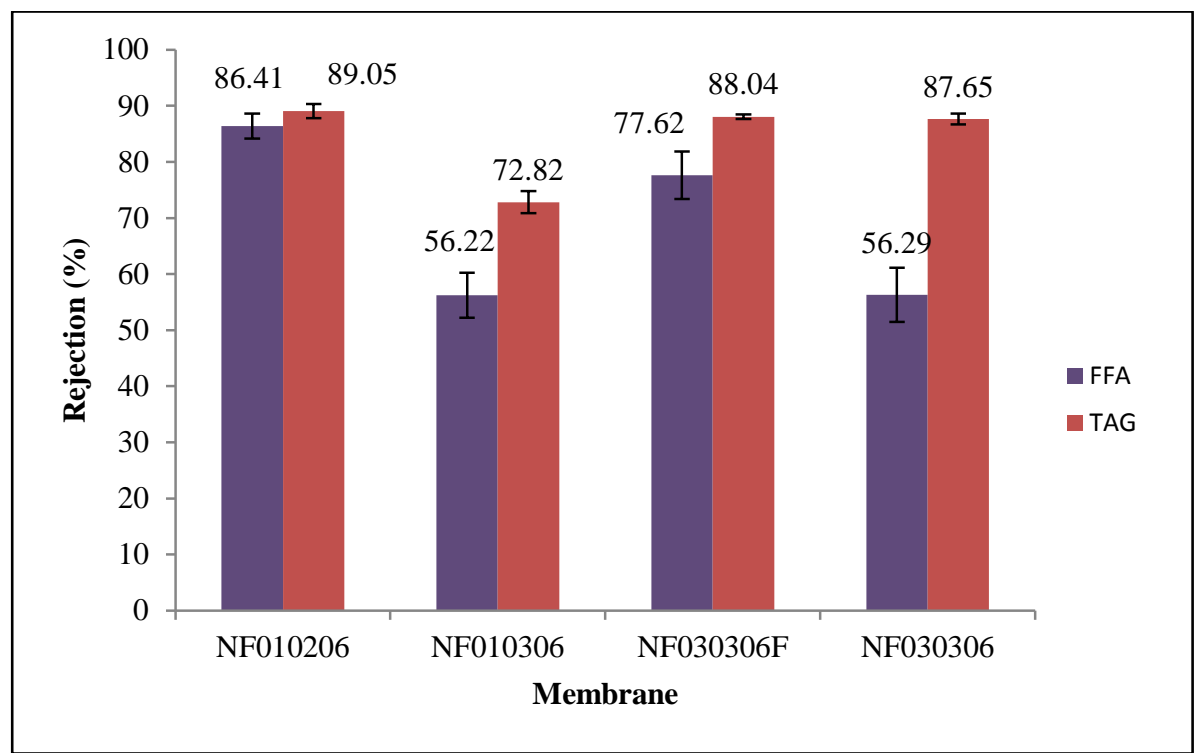

Figure 2. The effect of different type of membranes on the rejection of FFA and TAG at $30 \mathrm{bar}, 25{ }^{\circ} \mathrm{C}$ and $400 \mathrm{rpm}$. FFA concentration of $3.6 \mathrm{~g} / \mathrm{L}$ ( $4 \mathrm{wt} . \%$ FFA in $10 \mathrm{wt} . \% \mathrm{TAG}$ ).

Being the most permeable membrane to free fatty acid, with low free fatty acid rejection (56.29\%), high percent rejection of triglycerides $(87.65 \%)$, the NF030306 membrane was been selected for further optimization study.

\section{The effects of transmembrane pressure}

To evaluate the influence of transmembrane pressure towards the separation process, permeate flux was first evaluated. The permeate flux as a function of transmembrane pressure was shown in Figure 3. From Figure 3, the increase in pressure from 10 bar to 40 bar resulted in the increase of permeate flux from $18.4 \%$ to approximately 29.4\%. This nonlinear behavior was probably caused by the build-up of rejected solute (palm oil) near the membrane surface. Shi et al. [17] suggested that in systems with retained solutes, concentration polarization becomes stronger as flux increases. This concentration polarization increased the osmotic pressure near the membrane surface and consequently lead to a lower effective driving pressure.

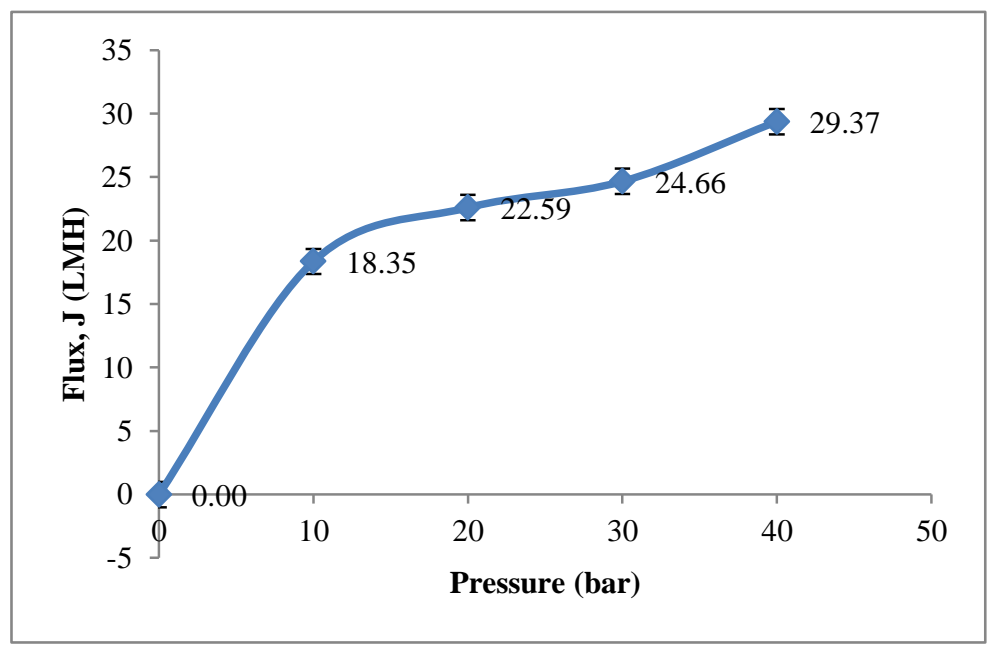

Figure 3. The effect of pressure towards flux (Operation conditions: $25{ }^{\circ} \mathrm{C}$ and agitation $400 \mathrm{rpm}$ with FFA concentration of $3.6 \mathrm{~g} / \mathrm{L}$ ( $4 \mathrm{wt} . \%$ FFA in $10 \mathrm{wt} . \% \mathrm{TAG}$ ) using NF030306 membrane) 
The rejection of free fatty acid and rejection of triglycerides at different pressures were evaluated and shown in Figure 4 and Figure 5, respectively. The rejection of free fatty acid decreased from $68.8 \%$ to $54.51 \%$ at the pressure of $10 \mathrm{bar}$ and $40 \mathrm{bar}$, while the rejection of triglyceride increased from 79.3 and $86.8 \%$. It is postulated that the rejection of free fatty acid decreased probably due to affinity towards the membrane.

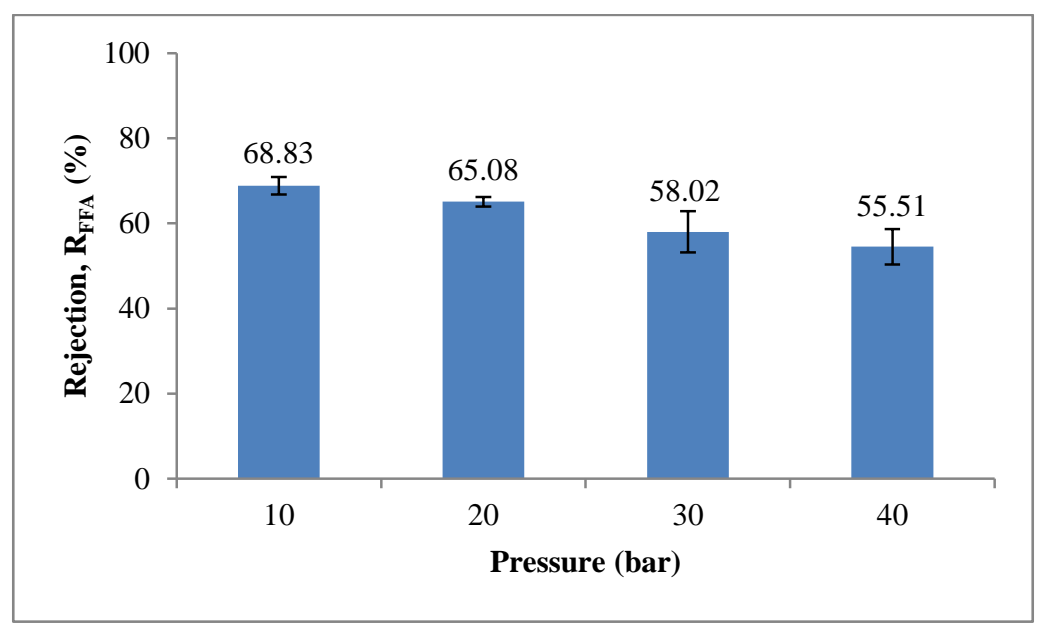

Figure 4. The effects of pressure towards rejections of FFA (Operation conditions: $25^{\circ} \mathrm{C}$ and agitation $400 \mathrm{rpm}$ with FFA concentration of $3.6 \mathrm{~g} / \mathrm{L}$ (4 wt.\% FFA in $10 \mathrm{wt} . \%$ TAG) using NF030306 membrane)

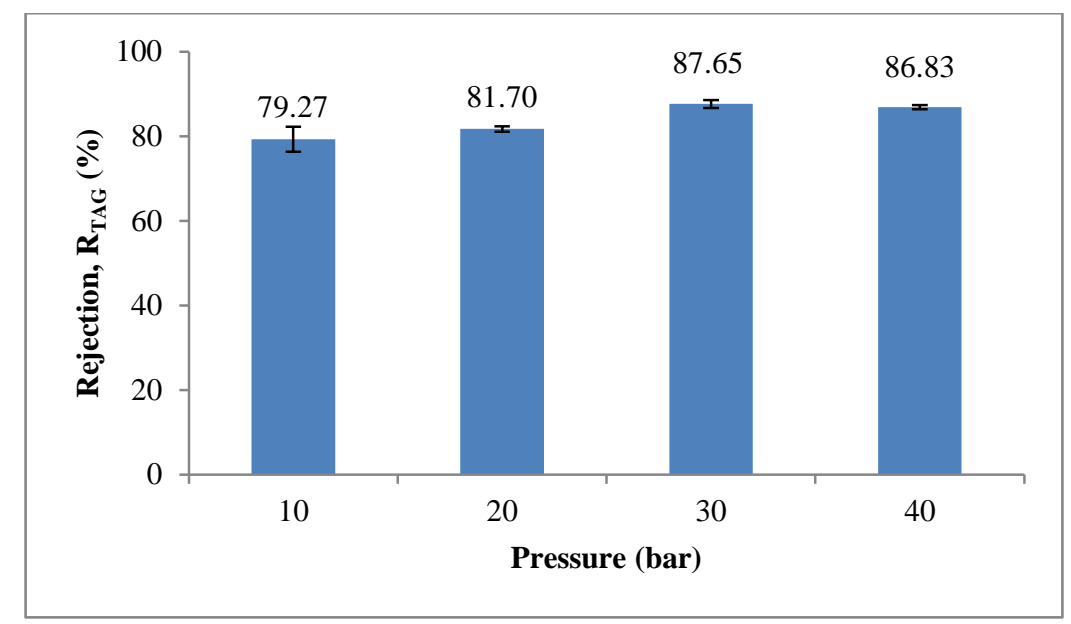

Figure 5. The effects of pressure towards rejection of TAG (Operation conditions: $25^{\circ} \mathrm{C}$ and agitation $400 \mathrm{rpm}$ with FFA concentration of $3.6 \mathrm{~g} / \mathrm{L}$ (4 wt.\% FFA in $10 \mathrm{wt} . \%$ TAG) using NF030306 membrane)

\section{Effects of FFA concentrations}

To evaluate the influence of fatty acid concentration towards the separation process, permeate flux was first evaluated. From Figure 6, the permeate flux decreased when the concentrations of feed increased. Permeate flux when the concentration of free fatty acid at $14.4 \mathrm{~g} / \mathrm{L}$ was four times lower than that using $1.7 \mathrm{~g} / \mathrm{L}$ concentration of free fatty acid. The decrease in flux was expected to occur especially with increasing viscosity due to high concentration of solutes. 


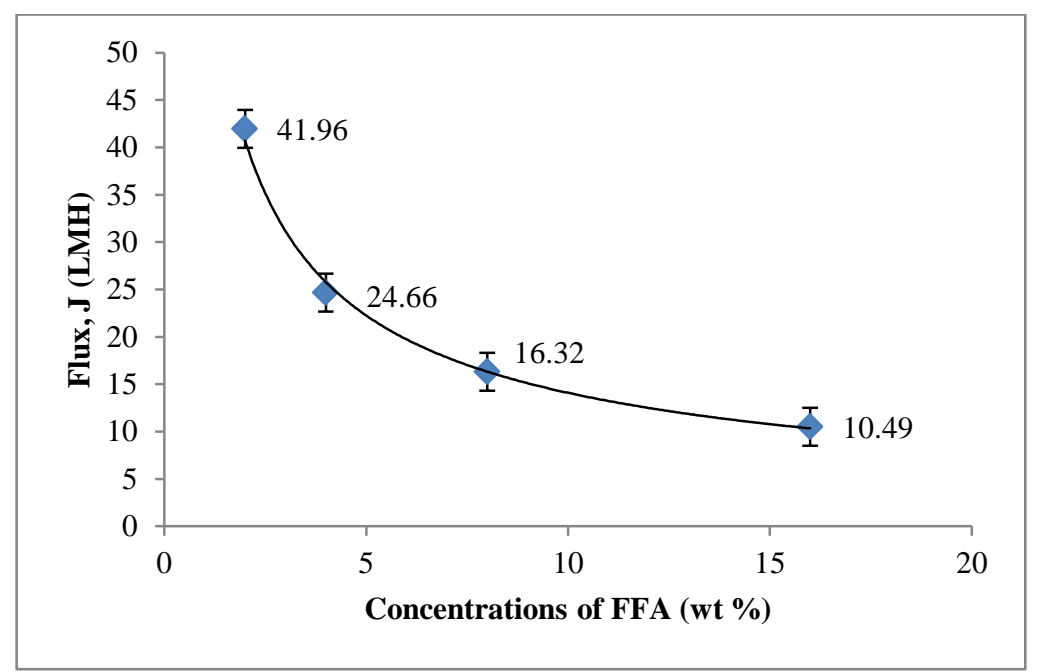

Figure 6. The effect of FFA concentration towards flux (Operation conditions: 30 bar $25^{\circ} \mathrm{C}$ and agitation $400 \mathrm{rpm}$ using NF030306 membrane)

Next, the rejection of free fatty acid and triglycerides at different free fatty acid concentrations were evaluated. From Figure 7 and Figure 8, the rejection of free fatty acid decreased and triglycerides were constant as the concentration increased. According to Bhosle et al. [2], the increase in the concentration of free fatty acid results in increased diffusivity as they are concentration dependent, and resulted in lower rejection of free fatty acid. However, different observations are reported in OSN literature regarding the concentration effects on the rejection. Zwijnenberg et al. reported constant rejection [18] while Whu showed that the rejection increased with concentration of solutes [19]. Triglyceride rejection was constant probably due to its large molecular size compared to the apparent membrane MWCO cutoff, so most of the triglyceride was retained in the retentate at high rejection regardless of the concentration. It was concluded that the different observation of rejection was due to type of solutes and membranes involved and the interactions between them. It can be noted that the rejection profile depends not only on the molecular size of solute but also on the affinity of the solute towards the membrane.

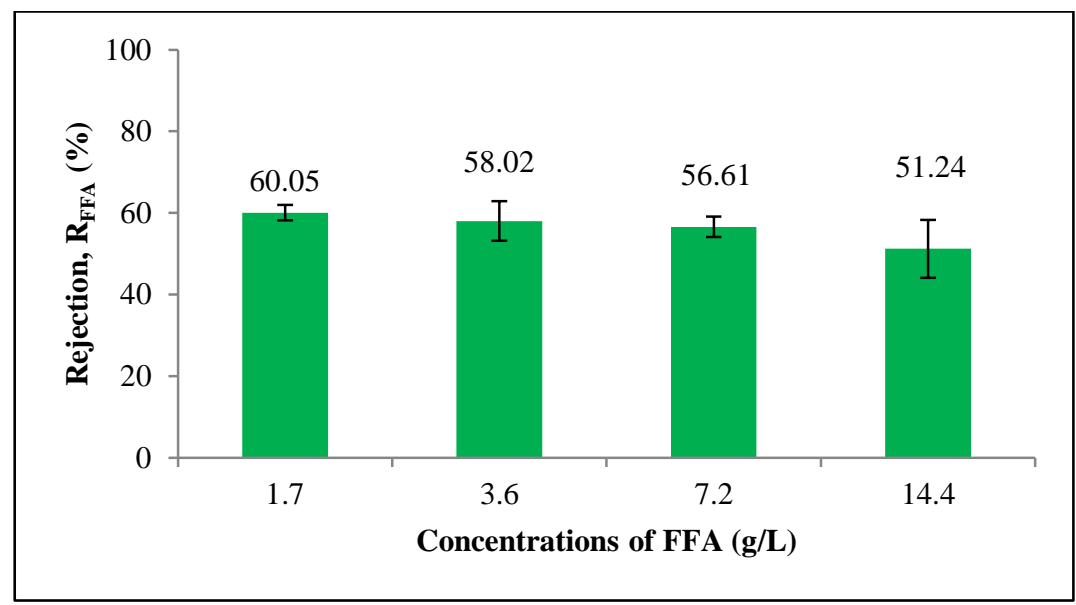

Figure 7. The effects of concentration of FFA towards rejection of FFA (Operation conditions: 30 bar $25^{\circ} \mathrm{C}$ and agitation 400 rpm using NF030306 membrane) 


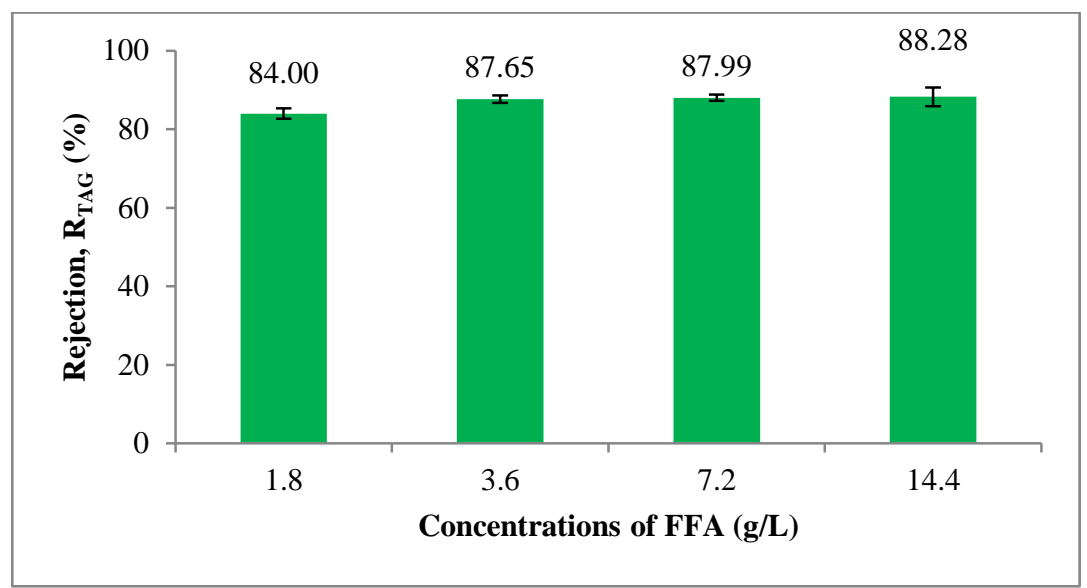

Figure 8. The effects of concentration of FFA towards rejection of TAG (Operation conditions: 30 bar $25{ }^{\circ} \mathrm{C}$ and agitation 400 rpm using NF030306 membrane)

\section{Conclusion}

The results successfully demonstrated the feasibility of fatty acid separation from palm oil using OSN. Based on results, the applied pressure increased the performance of the membrane. In all membranes, while FFA was permeated through them, the triglycerides (TAG) were found to predominantly retain. The best fatty acid separation performance was achieved using NF030306 membrane with acetone with the fatty acid rejection of 55\%, and the triglycerides rejection of $87 \%$. Good separation was achieved at high pressure (30 to 40 bar) and concentration (3.6 $\mathrm{g} / \mathrm{L}$ ). For these conditions, it is possible to deacidify palm oil/acetone mixture by using nanofiltration membranes. However, direct deacidification using nanofiltration membrane remains a challenge and in the need of more selective membranes for the maximum efficiency in fatty acid separation from crude palm oil.

\section{Acknowledgment}

The authors wish to thank UTM for support under GUP Tier 1 (14H20) and FRGS grant (4F616).

\section{References}

1. Rossi, M, Gianazza, M., Alamprese, C. and Stanga, F. (2001). The effect of bleaching and physical refining on color and minor components of palm oil. Journal of the American Oil Chemists' Society, 78 (10): 1051-1055.

2. Bhosle, B. M., Subramanian, R. and Ebert, K. (2005). Deacidification of model vegetable oils using polymeric membranes. European Journal of Lipid Science and Technology, 107: 746-753.

3. Raman, L. P., Cheryan, M. and Rajagopalan, N. (1996). Deacidification of soybean oil by membrane technology. Journal of the American Oil Chemists' Society, 73(2): 219-224.

4. Kale, V., Katikaneni, S. P. R. and Cheryan, M. (1999). Deacidification rice bran oil by solvent extraction and membrane technology. Journal of the American Oil Chemists' Society, 76(6): 723-727.

5. Kumar, N. S. and Bhowmick, D. N. (1996). Separation of fatty acids/triacylglycerol by membranes. Journal of the American Oil Chemists' Society, 73(3): 399-401.

6. Firman, L. R., Ochoa, N. A., Marchese, J. and Pagliero, C. L. (2013). Deacidification and solvent recovery of soybean oil by nanofiltration membranes. Journal of Membrane Science, 431: 187-196.

7. Vandezande, P., Gevers, L. E. M. and Vankelecom, I. F. J. (2008). Solvent resistant nanofiltration: Separating on a molecular level. Chemical Society Reviews, 37(2): 365-05.

8. Marchetti, P., Solomon, M. F. J, Szekely, G. and Livingston, A. G. (2014). Molecular separation with organic solvent nanofiltration: A critical review. Chemical Review, 114(21): 10735-10806.

9. Rundquist, E. M., Pink, C. J. and Livingston, A. G. (2012). Organic solvent nanofiltration: A potential alternative to distillation for solvent recovery from crystallisation mother liquors. Green Chemistry, 14(8): 21972205. 
10. Schaepertoens, M., Didaskalou, C., Kim, J. F., Livingston, A. G. and Szekely, G. (2016). Solvent recycle with imperfect membranes: A semi-continuous workaround for diafiltration. Journal of Membrane Science, 514: 646-658.

11. Dreimann, J. M., Skiborowski, M., Behr, A. And Vorholt, A. J. (2016). Recycling homogeneous catalysts simply by organic solvent nanofiltration: new ways to efficient catalysis. ChemCatChem 2 8(21): 3330-3333.

12. Ghazali, N. F., Ferreira, F. C., White, A. J. P. and Livingston, A. G. (2006). Chiral separation by enantioselective inclusion complexation-organic solvent nanofiltration. Desalination, 199: 398-400.

13. Kim, J. F., Gaffney, P. R. J., Valtcheva, I. B., Williams, G., Buswell, A. M., Anson, M. S. and Livingston, A.G. (2016). Organic solvent nanofiltration (OSN): A new technology platform for liquid-phase oligonucleotide synthesis (LPOS). Organic Process Research and Development, 20(8): 1439-1452.

14. Székely, G., Bandarra, J., Heggie, W., Sellergren, B. and Ferreira, F. C. (2011). Organic solvent nanofiltration: A platform for removal of genotoxins from active pharmaceutical ingredients. Journal of Membrane Science, 381(1): 21-33.

15. Goncalves, C. B. and Meirelles, A. J. A. (2004). Liquid-liquid equilibrium data for the system palm oil + fatty acid + ethanol + water at 318.2 K. Fluid Phase Equilibria, 221(1-2): 139-150.

16. Sablani, S. S., Goosen, M. F. A., Al-Belushi, R. and Wilf, M. (2001). Concentration polarization in ultrafiltration and reverse osmosis: A critical review. Desalination, 141(3): 269-289.

17. Shi, B., Marchetti, P., Peshev, D., Zhang, S. and Livingston, A. (2017). Will ultra-high permeance membranes lead to ultra-efficient processes? challenges for molecular separations in liquid systems. Journal of Membrane Science, 525: 35-47.

18. Zwijnenberg, H. J., Krosse, A. M., Ebert, K., Peinemeann, K. V. and Cuperus, F. P. (1999). Acetone-stable nanofiltration membranes in deacidifying vegetable oil. Journal of the American Oil Chemist' Society, 76(1): 83-87.

19. Whu, J. A., Baltzis, B. C. and Sirkar, K. K. (2000). Nanofiltration studies of larger organic microsolutes in methanol solutions. Journal of Membrane Science, 170(2): 159-172. 